\title{
THE ENVIRONMENTAL DRIVERS BEHIND THE DEVELOPMENT OF THE VICTORIAN TEXTILE FACTORY
}

\author{
Dampak Lingkungan yang Terjadi di Balik Pembangunan Pabrik Tekstil Victorian
}

\author{
Suci Farahdilla \\ Program Studi Arsitektur, Fakultas Teknik UNMUHA (sucifarahdilla@gmail.com)
}

\begin{abstract}
ABSTRAK
Industri tekstil di abad kesembilan belas Kerajaan Inggris Raya adalah salah satu tonggak sejarah industrl yang berpusat pada pabrik-pabrik kapas. Perkembangan industri ini menarik banyak warga yang menaruh harapan untuk meningkatkan standar hidup mereka dengan pindah ke daerah yang berdekatan dengan pabrik. Selain memberikan pemasukan bagi negara, pabrik-pabrik ini juga berdampak pada lingkungan serta masyarakat yang tinggal dan bekerja di dalamnya. Ada tiga masalah lingkungan yang muncul sebagai dampak dari industri pabrik tekstil masa Victoria yaitu: bahaya kebakaran, kondisi pabrik yang buruk dan RUU Pabrik. Bahan yang mudah terbakar, seperti kapas mentah yang terutama digunakan dalam industri ini, dan ruangan bersuhu tinggi menyebabkan pabrik-pabrik dilalap api. Kurangnya perlindungan konstruksi pabrik dari kebakaran menyebabkan diperkenalkan dan diterapkannya metode bangunan baru yang disebut "Konstruksi Tahan Api". Kondisi kesehatan para pekerja yang memprihatinkan karena bekerja di kelembaban dan suhu tinggi berujung dengan disahkannya RUU Pabrik (Factory Act). Namun, tindakan yang seharusnya menjadi aturan bagi pemilik pabrik untuk memberikan pekerja mereka tempat kerja yang jauh lebih layak hampir tidak terlaksana sepenuhnya pada masa ini. Penulis menggunakan metode studi pustaka dalam mengumpulkan data. Oleh karena itu, artikel ini dimaksudkan untuk menyampaikan kepada pembaca tentang situasi lingkungan di pabrik kapas sekaligus memberikan gambaran tentang betapa sulitnya mencapai kenyamanan yang ideal.
\end{abstract}

Kata kunci: Kenyamanan, Pabrik kapas, Lingkungan, RUU Pabrik, Kerajaan Inggris abad kesembilan belas, industri tekstil masa Victoria

\begin{abstract}
Textile industry in the nineteenth century of the British Empire was one of the milestone industries which center on cotton mills. The development of this industry attracted many people who wished to increase their life' standard to migrate to area near the factories located in order to work there. As much as giving revenue for the country, these factories also gave impact to the environment as well as people living and working in it. There were three things behind the environmental impact during the Victorian era of textile industry, fire hazard, mills' poor conditions and factory bill. Flammable materials, like raw cotton which mainly used in this industry, and high temperature room caused the factories engulfed in fire. The lacked protection from fire of the factories' construction then led to a new building method being introduced and applied called the "Fireproof Construction". Poor health condition of the workers who worked in high humidity and temperature of cotton mills brought a creation of factory bill (Factory Act) being passed. However, the act that was supposed to act as a regulation for factories owners to offer their worker a much more suitable place to work was hardly fully implied during this time. The writer used literature review method in collecting data. This article therefore intended to deliver the reader about the environment situation in the cotton factories while also giving the idea on how hardly an ideal comfort was achieved.
\end{abstract}

Keywords: Comfort, Cotton mills, Environmental, Factory act, Nineteenth century of British Empire, Victoria's textile industry

\begin{tabular}{lll}
\hline Article History & & \\
\hline Diterima (Received) & $:$ & $17-06-2021$ \\
Diperbaiki (Revised) & $:$ & $29-06-2021$ \\
Diterima (Accepted) & $:$ & $30-06-2021$
\end{tabular}


Rumôh

Journal of Architecture - University of Muhammadiyah Aceh Vol: 11 |No: 1 (2021): June

\section{INTRODUCTION}

British Empire in the nineteenth century, ruled by Queen Victoria, was the time when its popularity rocketed. It was an astonishing rate of the development in industrial centres (usually located in cities or towns such as London, Manchester, Lancashire and Liverpool), attracted people to come and live there. A huge number of people migrated from the countryside and Europe to Great Britain hoping that they could get a better paid job. It was not a surprise when its population exploded. 8.3 million people recorded living in the early nineteenth century of The United Kingdom. In 1801 (as cited from Harvie, Christopher \& Matthew, H.C.G, (2000)) the percentage of the mainland British lived in towns exceeded 30 percent, 21 percent in towns with over 10.000 populations and no more than a quarter of this figure lived in industrial towns. Majority of migrants were from working class and worked for industrial sites. Furthermore, industrialization British Empire cannot be separated from the rise of textile industries. It became one of dominant industrial centres besides agriculture, coal, and iron which towed the glider of Victorian industrialization into the air.

Cotton mills or cotton factories were one of the common textile industries in the nineteenth century England. Cotton was chosen, although the domination of linen, because its adaptability to machine production. Technology of machinery should be powerful enough to drive thousands of spindles for mills. Before the nineteenth century, cotton industries were home industries. Because of the rising demand for cotton garments, these small scale industries could not effort to fulfill the overwhelming need for it. Therefore, in the early Victorian times, cotton industries started to build factories and warehouses to accommodate thousands weaving and spinning machine. Cotton factories become important commodity which contributed to England's income and foreign exchange. However, in any profit brought by cotton factories, there was effect to the environment as well, both nature and human who involved in it. There are three environmental drivers that drove the development of Victorian Textile Factory (in this case is Cotton Factory or Cotton Mill), fire hazard, mills' poor conditions and factory bill.

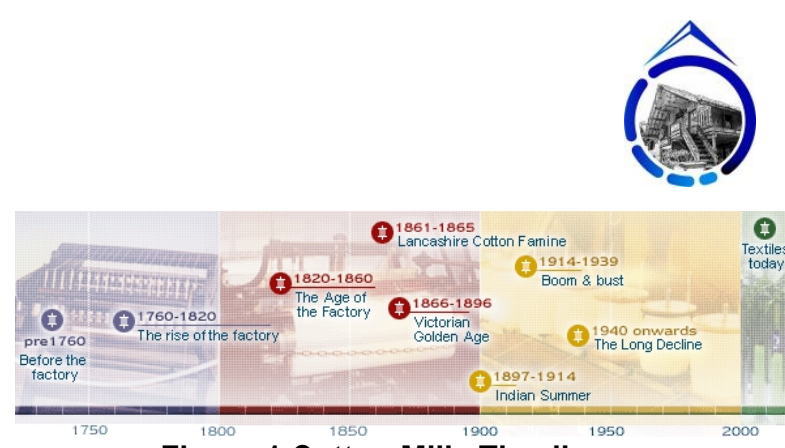

Figure 1 Cotton Mills Timeline

(Source: Spinning the web, 2013)

\section{METHODOLOGY}

This journal article is written purely using literature review from books, journals, online sources and historical achieves.

\section{DISCUSSION}

\subsection{Fire Hazard}

The first environmental drivers would be about fire hazard which made people suffered and drove the innovation of new design and technology development of incombustible factory building in the nineteenth century.

Since before the Victorian time, the development of cotton industry was rapidly dominated by massive factories. Cotton mill and warehouses were built in some part of England (such as Nottingham, Liverpool, London, Derbyshire, Glasgow and Bristol) and Lancashire became the main area of cotton production as well as Manchester. Flammable materials, for instance; raw cotton, were always easy to find in cotton mills. Either cotton fibers that floating in the air causing the creation of an explosive atmosphere or raw cotton's bales spontaneous combustion, the earliest version of cotton factories were vulnerable to fire. Disastrous fire once attacked in Mr. Jowett's mill, at Ashtonunder-Lyne in 1838. A half of the mill and its machinery were completely destroyed making nearly 400 labors lost their employment. Faced by these frequent fires, strong intentions were created to find a solution to overcome this problem. Mills built of brick with internal cast columns supporting the floor and coated plaster for the exposed beams surfaces was the first effort to avoid severe damage caused by unwanted fire. The floor consisted of stone flag, tiles or heavy timber which less able to catch fire.

Replacing the timber beams with cast iron beams was the next attempt. The name 'Fireproof Construction' was referred to this iron-framed mills. The development in searching for the best way to prevent fire in mills continued until curtain wall cladding used instead of thick load-bearing exterior wall. Newton Moor Cotton Spinning Co Ltd. owned two mills, Victoria and Albert Mills, which were built 
Rumôh

Journal of Architecture - University of Muhammadiyah Aceh Vol: 11 No: 1 (2021): June

in 1873 applying fireproof construction of cast-iron columns. This design allowed thinner exterior walls. Unlike the protection given by mills' owner for the factory buildings, less of them consider the need of comfortable place for worker to work as an important thing.

\subsection{Mills' Poor Condition}

"You know the scene: the great oblong ugly factory, in five or six tiers, all windows, alive with lights on dark winter's morning, and again with the same light in the evening; and all day within, the thump and scream of the thick smell of hot oil and cotton fluff and outside the sad smoke-laden sky and rows of dingy streets and tall chimneys belching dirt, and at the same, same outlook for miles" Edward Carpenter in Spinning The Web

The quote above illustrated cotton factories in the end of eighteen century to the beginning of nineteenth century. It was the time when the cotton industry gained its fame and developed its technology. Carpenter mentioned about the same light for day and night time in the cotton mills (this might be referred to gas lamp which commonly used at the beginning of the Victorian era) and described the air condition inside the mill as hot and thick with cotton fluff while outside the mills was polluted air containing smoke. Giving those descriptions, the next environmental driver that drove the development of Victorian cotton factory was poor condition of the mills in the nineteenth century.

In the mills, work for labors were either around spinning or weaving, sometimes including bleaching and dyeing. Both spinning and weaving in the nineteenth century was done using machinery powered by water before developed to be a steam powered engine. To achieve the best cotton quality, spinning and weaving should be done in warm and humid temperature. At least $50-54 \%$ of relative humidity was needed for cotton spinning whereas ideal weaving desired 76\% (Lander (1914) in Craft, Nicholas and Wolf, Nikolaus (2012)). Therefore, to avoid the thread from breaking, the air in the cotton mills should be kept 65 to 80 degree. Furthermore, unfiltered heat and smoke from machines' combustion increased indoor temperature and pollution. In this temperature, the workers' health could be seriously damaged and thick air contained cotton dust in mills could lead to byssinosis - a lung disease. To prevent this condition, the labors were persuaded to use protective mask. In humid and warm temperature, wearing a mask was not a good option as they felt uncomfortable about it.

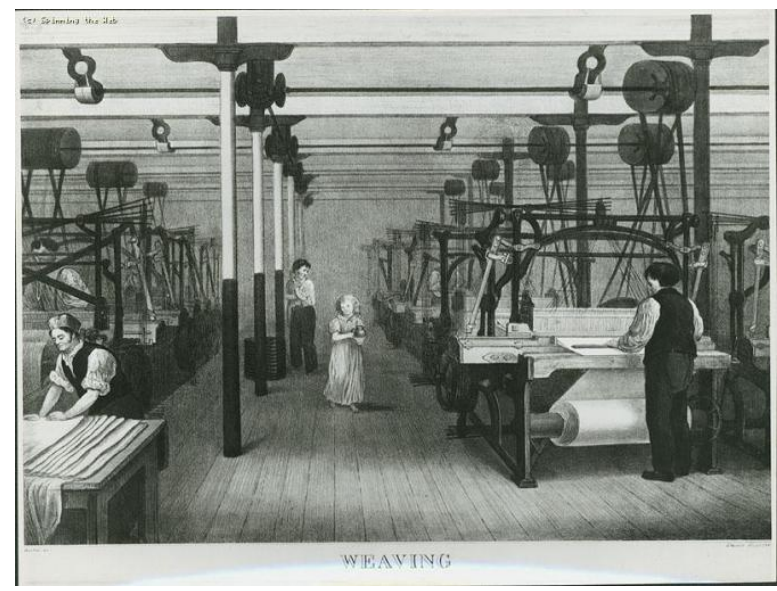

Figure 2 Weaving in the nineteenth century, 1820-1860

(Source: Spinning the web, 2013)

In 1875, 1600 operative bleacher and dyer revealed that bleachers' work was done in a very high temperature room and seldom in the open air. The workers need to be in open air to release their stress after working in stuffy room with unbelievable temperature (diffused heat from machinery could hit approximately 120 degree). The men usually undress altogether while doing their work. Health and Safety Executive (HSE) stated that the minimum normal temperature for workplace at least 16 degree in Celsius (around 60 degree in Fahrenheit) or 13 degree in Celsius (around 55 degree in Fahrenheit) if it was physical work. The Workplace (Health, Safety and Welfare) Regulations 1992 also mentioned 'During working hours, the temperature in all workplaces inside buildings shall be reasonable'. The reality faced by labors in the nineteenth century British Empire was far from the number. In uncomfortable hot and humid temperature, labors could gradually lose their concentration and even threatened themselves.

Making condition worsened was the height of the workroom. Touchable ceilings indicate that the ceilings in the factories building were very low which did not fit to HSE guide regarding room dimensions and space. Enough free space in workroom should be provided to allow people to do their activities easily. HSE also explained, based on The Workplace (Health, Safety and Welfare) Regulation 1992, the volume of the empty room should be at least 11 cubic meters after divided by the number of people normally working in it and all or part of a room over $3.0 \mathrm{~m}$ high should be counted as $3.0 \mathrm{~m}$ high. Touchable ceilings mean they had height lower 
than $3.0 \mathrm{~m}$ and might leave impression of stuffy room.

Furthermore, a newspaper article in the end of the nineteenth century wrote about an inspector visited and checked mills' condition in Lancashire. The mills were said to be insanitary with lavatories opened directly out of room and without ventilation. Majority mills had inadequate and frequently sealed ventilation. Even worse case where ventilation did not exist was found in many mills in the Nelson district. In this case, the room was full of Carbon Dioxide $\left(\mathrm{CO}_{2}\right)$ created low Oxygen $\left(\mathrm{O}_{2}\right)$ level for human that could leave harmful effect to physical ability and brain function. In point of fact, such a hot condition mills plus minimum Oxygen level caused weavers to faint and this was admitted by the mills' manager. The weavers who work almost everyday also complained about having rheumatic pains and general prostration. In the summer time, they work inside excessive heat of room with less effective ventilation and their affliction got worse in winter. Working all day long in high temperature room and then after finished working, suddenly freezing breeze attack their fatigue body. This condition might be life threatening for human health as it will lead to disease or metabolic disorder such as hypothermia (when normal body temperature which is $37^{\circ} \mathrm{C}$ drops below $35^{\circ} \mathrm{C}$ ). To prevent all disadvantages, a cotton factory workroom should have proper ventilation where fresh and clean air could be drown from outdoor and remove as well as dilute hot temperature, humid air and provide air movement. Due to owners' passiveness, such ventilations were hardly ever found here.

\subsection{Factory Bill (Factory Act)}

The last environmental driver that drove the development of cotton factory in the nineteenth century was factory bill (widely known as factory act).

As a common industrial site since the early Victorian, textile factories required many workers to operate the factory. The owners employed labors from working class, people who came attracted by the better paid jobs in textile production. Both adults and children employed in the cotton mills which lead to result around $49 \%$ of labors in 1821 were young apprentice, children under 20 . The reasons behind the employment of these children were because of easier to discipline and low salary. This action leads to protest from people who concerned to see 'pauper labors' were treated badly. The very first factory legislation promoted by Sir Robert Peel, an MP and a wealthy factory owner known as Peel's Act which prevented night working time, 12 hours working time a day for labors up to 21 years old and they also obliged to receive basic education. Because the lack enforced to this act, it then followed by the Cotton Mills Act in 1819, known as Cotton Mills Act, which treated same as its predecessor. The pioneering piece of legislation was passed by the Parliament in 1833 known as The 1833 Factory Act. The factory act reported to let no children under the age of nine working in factories. Children between the age 9 and 13 could work for 48 hours per week ( 8 hours per day) and those who aged 13 to 18 limited to 12 hours per day. This act applied to both the cotton industry and older woolen producing communities.

The first act concerning health and safety was passed in 1844. The act stated that all machinery must securely fenced off and while the engine on, no children was to clean it. Maximum 12 hours a day for those age 13 to 18 (this motion also applied to women) and 3 hours education plus 6.5 hours limited working time also set for children. Further act of 1847 was campaigned by Anthony Ashley-Cooper regarding 10 hours work for women and children between 13 and 18. Several acts in 1867, 1878, 1891 and 1895 brought improvement and extended safety regulation to the working condition of laboring people in workshops and factories. The act which laid down in 1891 (later extended in 1895) especially mentioned about the safety and sanitary regulations lead to notifiable of some industrial disease (e.g. those caused by lead, arsenic, phosphorus and anthrax).

The act should act as the regulation for factories' owner to be more concerned with their employee and created the best place for them to work. However, the effectiveness of the acts was questioned by a lot of people. Many irresponsible mills' owner acted indifferently toward the acts. One famous cases of broken act was in 1859 when a little 'scavenger' girl, Martha Appleton, who employed to pick up loose cotton beneath the factory's machine, was found fainted one day and caught her hand in an unguarded machine. In that accident, her fingers were severed and she lost her job. Another case was mention before about insanitary mills found by inspector in Lancashire. 


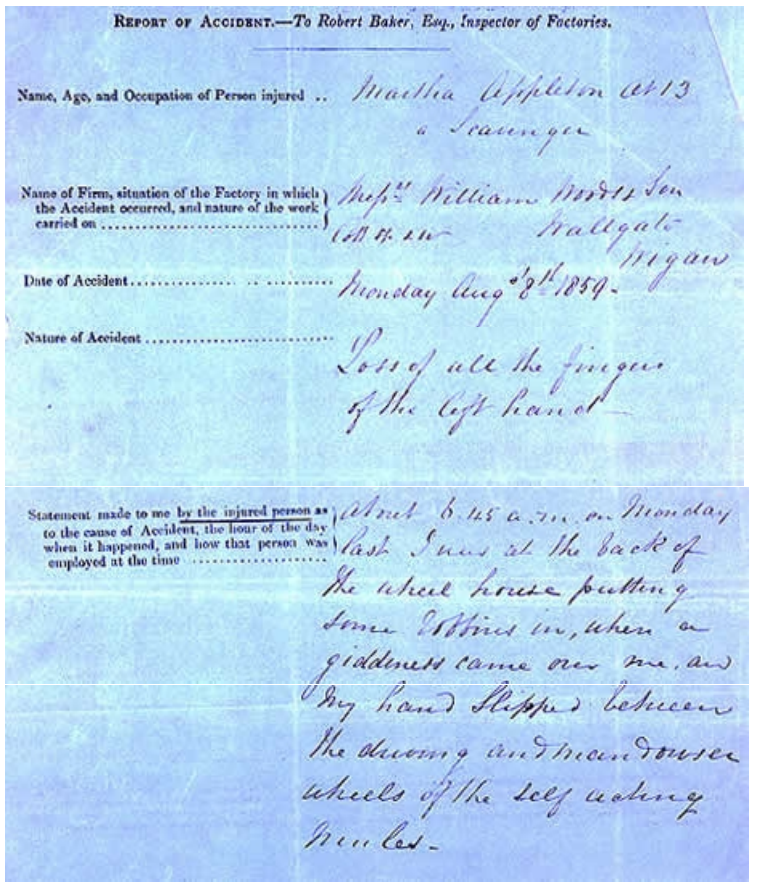

Figure 3 Report of Martha Appleton's accident, 1859

(Source: The National Archive)

\section{DISCUSSION}

The cotton mills or cotton factories grown up in the later eighteen century then climbed to be one of the top industrial sectors in the nineteenth century. Environmental drivers play an important role driven the development of Victorian cotton factory in such a way that it affected to building and people who participated in it. There were unpleasant events (fire attacked the factory building) happened in the mills and many people lose their livelihood, poor mills condition happened created an uncomfortable working environment and these all lead to protest then resulting factory bill (factory act) to be passed.

Ideal condition of the cotton mills in the nineteenth century of United Kingdom was hardly achieved. Either ignorant mills' owner or imperfect regulation at that time could be favorite reasons why this happened. Mills' owner concerned about how to prevent their building from being destroyed by fire rather than how to make their workers comfortable while working in their factory. Disobeying the regulation was mills' owner responsibility because the one that can lead the change of their own property was themselves. They were also responsible for maintaining the best work environment. Keeping the work environment comfortable can improve workers' productivity and quality of product as the demand of thermal comfort also stimulus people to work in stable state of both mental and physical. Nevertheless, this knowledge had not developed well around people at that time especially those engaged in business world where profit always come first.

\section{BIBLIOGRAPHY}

'The Factory and Workshop Acts Extension'. (1875). The Dundee Courier \& Argus Northern Warder (Dundee, Scotland), 2.

'A Lady Inspector in the Mills. Insanitary Mills in Preston'. (1893). The Weekly Standard and Express (Blackburn, England), 2.

Atkinson, Edward. (1883). Report on English Cotton Mills and Methods. Boston : Journal Of Commerce Publishing Company

Atwood, Rollin S. (1928). Localization of the Cotton Industry in Lancashire, England. Economic Geography, 4 (2), 187-195. [available online]

Banham, Reyner. (1984). The Architecture of the Well-Tempered Environment. The University of Chicago Press, London.

BBC Nation On Film 'A Factory Worker's Lot Conditions In The Mill'. Retrieved from http://www.bbc.co.uk/nationonfilm/topics/textiles Ibackground conditions.shtml accessed 27/10/2013

COPD Foundation, 'How Low Oxygen Levels Affect the Body'. Retrieved from http://www.copdbfrg.org/?page id=984 accessed 17/11/2013

Harvie, Christopher \& Matthew, H.C.G. (2000). Nineteenth-Century Britain, A Very Short Introduction, Oxford University Press Inc, New York.

Hansard Factories Regulation Bill. Retrieved from http://hansard.millbanksystems.com/lords/1819/j un/14/cotton-factories-regulationbill\#s1v0040p0 18190614 hol 3 accessed 20/10/2013

Hawkes, Dean. (2012). Architecture and Climate An Environmental History of British Architecture, 1600-2000. Routledge, New York.

Health and Safety Executive, 'What is the maximum/minimum temperature in the workplace?'. Retrieved from http://www.hse.gov.uk/contact/faqs/temperature. htm accessed 28/10/2013

Health and Safety Executive, 'Workplace health, safety and welfare. A short guide for managers'. Retrieved from http://www.hse.gov/uk/pubns/indg244.pdf accessed 17/11/2013 
Key dates in the Sociological history and development of Great Britain 'Key dates in Working Conditions, Factory Acts Great Britain 1300 - 1899'. Retrieved from http://www.thepotteries.org/dates/work.htm accessed 01/11/2013

Lambert, Tim, 'Life in the $19^{\text {th }}$ Century', 2013. Retrieved from http://www.localhistories.org/19thcent.html accessed 27/10/2013

Lander (1914) in Craft, Nicholas and Wolf, Nikolaus (2012) 'The Location of the British Cotton Textiles Industry in 1838 a Quantitative Analysis. Retrieved from http://cep.Ise.ac.uk/seminarpapers/13-01-12NC.pdf accessed 19/10/2013

Living Heritage 'Reforming society in the $19^{\text {th }}$ century - Early factory legislation'. Retrieved from http://www.parliament.uk/about/livingheritage/transformingsociety/livinglearning/19thc entury/overview/earlyfactorylegislation/ accessed 20/10/2013

Living Heritage 'Reforming society in the $19^{\text {th }}$ century -The 1833 Factory Act'. Retrieved from http://www.parliament.uk/about/livingheritage/transformingsociety/livinglearning/19thc entury/overview/factoryact/ accessed 20/10/2013

Marsden, Richard. (1903). Cotton Spinning: Its Development, Principles, and Practice. G. Bell, London.

Nashmith, Joseph. (1894). Recent Cotton Mill Construction and Engineering. J.Heywood, London.

Reid, David Bosswell. (1844). Illustrations of the Theory and Practice of Ventilation: With Remarks on Warming, Exclusive Lighting, and the Communication of Sound. Longman, Brown, Green, \& Longmans, Paternoster-Row, London.

Richard, Marsden. (1903). 'Cotton Spinning : It's Development, Principles, and Practice (1884)'. Retrieved from https://archive.org/details/cottonspinningit00mar s accessed 21/10/2013

Simmons, I.G. (2001). An Environmental History of Great Britain from 10,000 Years Ago To the Present. Edinburgh University Press Ltd., Edinburgh.

Spinning The Web - The Story of the Cotton Industry, 'Health and Safety Learning Journey'. Retrieved from http://www.spinningtheweb.org.uk/journey.php?
Title=Health+\%26+Safety+learning+journey\&ste $\mathrm{p}=6$ \&theme=industry accessed 17/11/2013

Strutt's North Mill Belper, 'Development of Fireproof Industrial Buildings'. Retrieved from http://belpernorthmill.org/about-themill/development-of-multi-storey-buildings/ accessed 28/10/2013

The Proceedings of The Old Bailey. (2013). 'Currency, Coinage and The Cost of Living'. Retrieved from http://www.oldbaileyonline.org/static/Coinage.js $\mathrm{p}$ accessed 27/10/2013

The National Archive 'Child Labour'. Retrieved from http://www.nationalarchives.gov.uk/pathways/citi zenship/struggle democracy/childlabour.htm accessed 20/10/2013

The Spectator Archive, '15 DECEMBER 1838, Page 5'. Retrieved from http://archive.spectator.co.uk/article/15thdecember-1838/5/a-fire-broke-out-in-theextensive-cotton-mills-of- accessed 31/10/2013

The Workplace (Health, Safety and Welfare) Regulations 1992. Retrieved from http://www.legislation.gov.uk/uksi/1992/3004/reg ulation/7/made accessed 28/10/2013

'Victoria and Albert Mills, Cotton Spinning Mills, Victoria Road, Cheshire' (2013). Retrieved from http://www.pittdixon.go-plus.net/v+a-mills/v+amills.htm accessed 31/10/2013

\section{PICTURE SOURCE}

Figure 1 Spinning the Web - Cotton Mills Timeline.

Source :

http://www.spinningtheweb.org.uk/overview/ accessed 30/10/2013

Figure 2 Spinning the Web - Weaving in the nineteenth century. Source :

http://www.spinningtheweb.org.uk/m display.ph $\mathrm{p}$ ?irn $=8 \&$ sub=overview\&theme $=0$ verview\&crum $\mathrm{b}=$ The+Age+of+the+Factory accessed 30/10/2013

Figure 3 The National Archive - Report of Martha Appleton's accident, 1859. Source : http://www.nationalarchives.gov.uk/pathways/citi zenship/struggle democracy/childlabour.htm accessed 20/10/2013

\footnotetext{
Kutipan Artikel

Farahdilla, Suci (2021). The Environmental Drivers

Behind The Development Of The Victorian Textile

Factory, Rumoh, 11 (1), 1-6: Juni.

DOl: http://doi.org/10.37598/rumoh.v11i1.130
} 